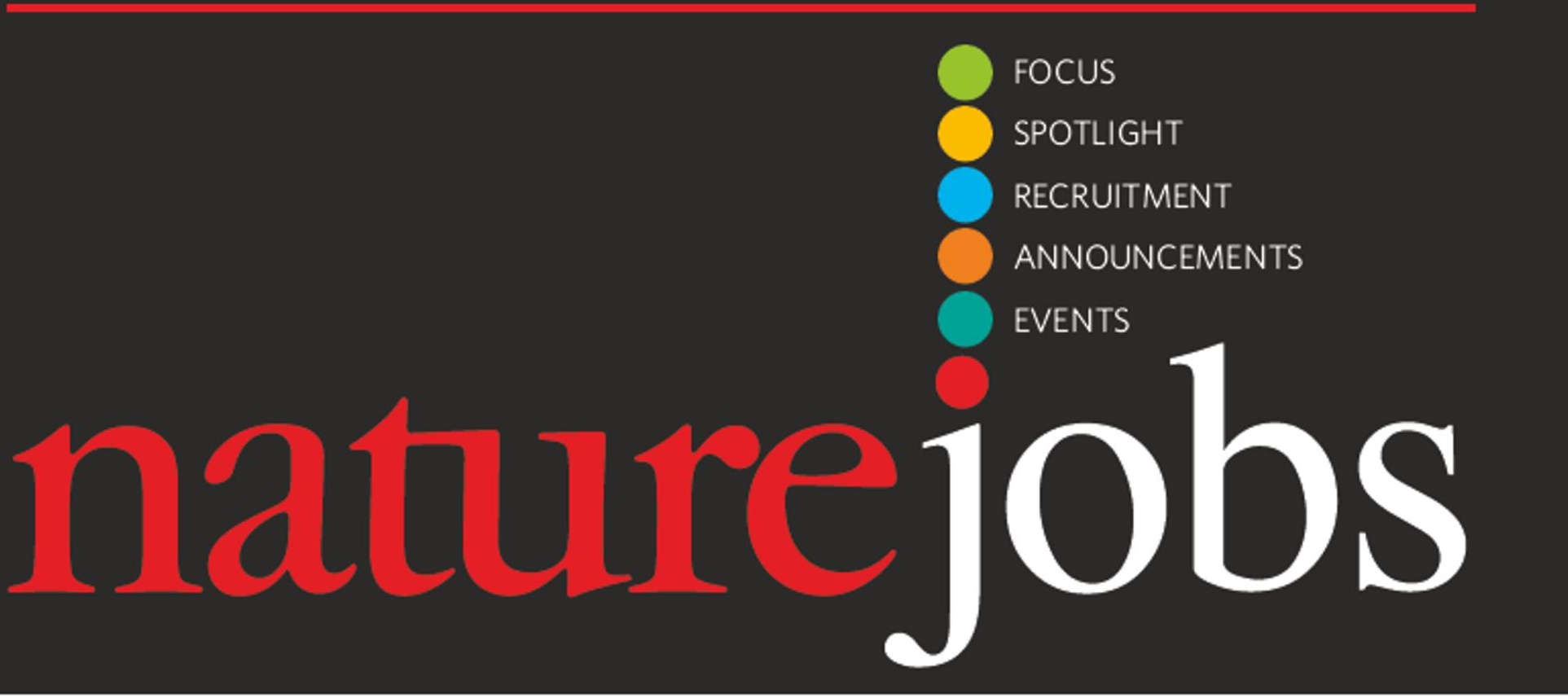

\section{A global view}

The past year seems to have been a good one for biotechnology, with the sector continuing to expand, according to a report issued this month by analysts Ernst \& Young. Beyond Borders: Global Biotechnology Report 2005 reveals that global biotech employment grew by $5 \%$ to 183,820 jobs over the period $2003-04$. A disproportionate number of those jobs $-137,400$ - are in the United States, which saw its public biotech employment grow by $10 \%$ in that period.

The picture is less rosy in Europe, which saw public biotech jobs fall by $21 \%$ to 25,640 , and in Canada, where the number of jobs dropped from 7,440 to 7,370. Asia-Pacific, on the other hand, saw rapid growth as it moved from having 9,810 jobs to 13,410 .

The experts cited in the Ernst \& Young report almost all agree that the biotech industry is aiming to cut the costs of drug development. And they also note that companies are more willing than ever to go global. But what will this mean for the future of biotech jobs?

For now, the big centres in the United States - especially Massachusetts and California - will continue to thrive, as they have a critical mass of infrastructure, investment and personnel. But as companies look to cut costs and outsource parts of their operation, Asia stands to gain - a trend that is apparent beyond biomanufacturing (see Nature 433, 902-903; 2005). And some Asian countries are already beginning to exploit gaps in research and development where politics may be creating obstacles in the United States - by promoting stem-cell science and therapeutic cloning, for instance.

Putting the numbers and trends together, then extrapolating a little, it seems safe to say that the number of jobs in the biotech sector will continue to grow for the next few years. But it is no longer safe to predict that the growth will take place in those places traditionally associated with the field.

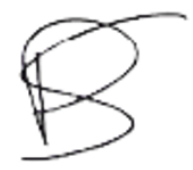

Paul Smaglik, Naturejobs editor
CONTACTS

Publisher:Ben Crowe

Editor: Paul Smaglik

Marketing Manager: David Bowen

US Head Olfice, New York

345 Park Avenue South 10th Floor,

New York, NY 10010-1707

Tet +18009897778

Fac +1 800989703

e-mail na turejobs@onsturenycom

US Sales Manazer/Corporations Peter Bless

Classfied Sales Representatives

Tet +18009897718

\begin{tabular}{|c|}
\hline $\begin{array}{l}\text { New York/Pennsylvania/ } \\
\text { Latin Americax Kelly Roman }\end{array}$ \\
\hline $\begin{array}{l}\text { Midwest USA/Maryland/ } \\
\text { NIIt: Wade Tucker } \\
\text { East USA Cana da: } \\
\text { Janine Tacrmina }\end{array}$ \\
\hline $\begin{array}{l}\text { San Francisco Office } \\
\text { Classified Sales Representative: } \\
\text { Michaela Bjorkman } \\
\text { West USAMU West Corp Canada }\end{array}$ \\
\hline $\begin{array}{l}225 \text { Bush Street, Sutte } 1453 \\
\text { San Francisca. CA } 94104 \\
\text { Tet }+14157813803 \\
\text { Fac }+14157813805 \\
\text { e-mat mbiokman@insturestcom }\end{array}$ \\
\hline
\end{tabular}

Europeen Head Office, London

The Macmillan Building.

$4 C$ rinan Street.

London N1 9XW, UK

Tet+44(0) 2078434961

$\mathrm{Fac}+44(0) 2078434996$

e-matitnaturejobs@onaturecom

Naturgio bs Sales Director: Nevin Bayoumi(4978) European Sales Mana ger: Andy Douglas (4975)

Advertising Production Manager : Bille Fanklin To send materials use London address above. Tet+44(0) 2078434814

$\mathrm{Fac}+44(0) 2078434996$

e-mail naturejobs@onturecom
Natirejiobs web development: Tam Hancock Naturejobs online production: Niamh Shields

Europeen SsteliteOffice

Patrick Phelan

e-maltp phelan@onsture com

Japan Head Office, Tokyo

Chiyoda Bulling.

2-37 Id igayatamachi.

Shinjuku-ku.

Tokyo 162-0843

Tet +81332678751

$\mathrm{Fac}+8133268746$

Adia-Pacific Sales Director: Rinolo Asami

e-mat tasamignaturejpncom 